\title{
Modernization of Russian district heating systems with the help of biomass energy - a Gordian knot?
}

\author{
Hilma Salonen \\ University of Helsinki, Finland \\ hilmasal@icloud.com
}

\begin{abstract}
The article discusses the prospects of local wood waste resources as replacements for fossil fuel imports in the remote settlements of the Russian North from a viewpoint of a case study: the Arkhangelsk region and its outdated heating and fossil fuel delivery systems. Drawing on energy transition literature and expert interviews, the most influential factors are defined in geographic-infrastructural, institutional, financial, and behavioral contexts. In conclusion, the article determines that a key issue is that the constraints for alternative energy sources reinforce each other, while the actors working for them find themselves in an isolated position. This is especially true for the institutional and financial constraints. However, by examining the enabling factors it is possible to see how the bundle of constraints could also be undone together. Most efficient way for success would likely be helping municipalities and actors in the fields of biomass and energy production to form joint clusters and share resources.
\end{abstract}

Keywords: renewable energy, energy transition, lock-in, district heating, Russia

Word count: 8384

Funding: This article has been funded by a grant from the Academy of Finland.

Declaration of interests: no interests to declare

\section{Introduction}

The heating season of the Russian North is known for its unsparing and relentless nature. With temperatures hitting $-25^{\circ} \mathrm{C}$ and much below, being able to trust in the consistency of heating is a prerequisite for the continuance of everyday life, business, and industry. In recent years, the Northwestern 'oblast' of Arkhangelsk, a region of $1,200,000$ people that is spread along the shores of the White Sea and the Barents Sea, has been struggling to ensure the stability of coal supply from its neighboring republic of Komi at wintertime. Local newspapers have revealed that the winter coal reserves have been insufficient and around half of the boilers of local power plants not suitable 
(C) 2021. This manuscript version is made available under the CC-BY-NC-ND 4.0

license https://creativecommons.org/licenses/by-nc-nd/4.0/

https://doi.org/10.1016/j.eist.2019.10.006

for winter use $(1,2)$. As a result of these problems, the price of heat, which has already experienced several price hikes in the 2010s, is at risk of increasing more, especially for far-flung settlements $(3,4)$. The issue of ensuring heat supply considers several sectors of the society due to the deep structural problems involved, such as the high wear and obsolescence of heating infrastructure, the long distances, and short transport seasons (5). Modernizing a highly centralized district heating system with market-based pricing systems has proven to be a difficult task (6). All these factors increase the share of fuel delivery and generation in the regional and municipal budgets: supply costs make up $80 \%$ of the final price for the end-user $(4,7)$.

At the same time, Arkhangelsk region has a lot of potential for replacing fossil fuels with its own renewable resources. The amount of biomass suitable for energy use has been estimated to be the highest in Russia after the Komi republic, and specially its wood waste resources are multifold compared to most other regions, covering $75 \%$ of the region's surface with the estimated potential of 4.8 million tons of timber processing waste produced $(8,9)$. At the moment, there are more than 400 boilers running on biomass and wood waste in Arkhangelsk (10). However, while the potential of biomass from forestry waste to energy use is exceptionally high, it is also considered very uncertain due to various barriers (7).

Using the Arkhangelsk region as a case study, this article seeks to explore the gaps between the potential of local resources, the official modernization and energy efficiency programs, and their implementation. Previous studies on Russian renewable energy politics give reason to believe that these issues are imbedded in the current system $(11,12,13)$. Ironically, modernization projects in Russia lacking the 'big' money reserved for priority projects prove often to be more viable economically (14), making them interesting pilot projects for energy transition research. At the same time, those most interested in carrying out sustainability transitions, such as local municipalities, often have the least resources for doing so (15). The combination of neglected, crumbling infrastructure and investment gaps have inflated the modernization needs of the communal heating sector to such an extent that a much more ambitious reform than mere tariff rises, for example, would be needed to cover their costs (12).

Sustainability transitions are never smooth processes but instead plagued with resistance from incumbent powers active in politics, business, and everyday life 
(16). Actors involved affect the whole process in active and passive ways, and this interplay is often analyzed by using the Multi-Level Perspective approach. The theory defines three levels of a socio-technical system where energy transition and resistance happen: landscape, regime, and niche $(17,18)$. The landscape refers to the broader context such as environmental, demographic, or cultural processes that are beyond the direct influence of the incumbent powers. In this article, the landscape level is understood, above all, as the pressure to improve energy delivery, storage, and distribution systems to offer better energy security. At the local level, this pressure appears as the need to repair the municipal heating networks and find more secure alternatives for fossil fuel imports during the heating season. As for the socio-technical regime, here it consists of the current heating system, with all of its actors and lobbies, practices and resource flows, and material elements such as infrastructure. The regime is inherently resistant to change, while ruptures in the landscape level and new opportunities offered by innovative niches create stress and may even destabilize its balance $(19,20)$. Niches benefit from the weaknesses of the regime and the external pressure of the landscape level as they are essentially new socio-technical practices, i.e., new solutions for existing problems (21). Although burning wood is an old heating solution especially in dachas and off-grid settlements, linking biomass usage to the broader district heating network is a relatively new development. Therefore, an example of niches is replacing old boilers of heating plants with ones that are able to burn biomass, or the possibility for sawmills to use their own residuals to produce heat. The outcome of a process involving all three levels is energy transition, whether gradual or more disruptive $(17,18)$. It is common that the transition begins by improving the existing energy systems instead of dismantling them (22).

The process of energy transition is still more hampered by the powerful inertia that all previous choices have produced, locking prevailing practices further into their place (23). Research on this phenomenon derives from the literature on MultiLevel Perspective and is known as the theory on carbon lock-ins, covering the various difficulties that attempts to introduce low carbon alternatives face from various already existing structures (23-25). While all investment projects are prone to path dependency, energy projects are particularly vulnerable due to the large-scale investments needed, the long wait for paybacks on them, and the long working life of existing energy 
(C) 2021. This manuscript version is made available under the CC-BY-NC-ND 4.0

license https://creativecommons.org/licenses/by-nc-nd/4.0/

https://doi.org/10.1016/j.eist.2019.10.006

infrastructure (26). As a result, low carbon transitions and the work for higher energy security and efficiency face difficulties everywhere in the world (27). Russian energy infrastructure's resistance to change is further reinforced by the Soviet legacy of central planning, the bundling of heat producers, industries, and institutions (28).

Despite the flexible and holistic nature of the Multi-Level Perspective, recent research has listed several issues that have been overlooked in its core literature, creating an overly simplistic view of the conditions surrounding sustainability transitions. Firstly, the 'regime' level is often portrayed as the source of inertia and lock-ins on the way of innovative practices, an assumption which reduces it into an assemblage of sanctions and policies, or even suggests that the regime itself is unable to partake in sustainability transitions (29). Therefore, drawing clear divisions between 'regime' and 'niche' players - for example by classifying regional energy companies into either group - is often too simplistic. Overemphasizing the role of one component, be it individual actors, technical innovations, or restriction posed by the regime, makes the socio-technical energy system seem like a monolithic entity, which fails to represent the local realities (30-32). Secondly, the theory on carbon lock-ins has been criticized for overemphasizing dependence on technology and thus leading to defeatist and general scenarios that are too detached from the local level (32-35). Instead, looking more closely into the relations between the socio-technical regimes and the energy complexes would provide more detailed information about the changes and resistance occurring during the energy transition process $(32,36)$.

To discuss these problems and lay ground for a more refined analysis, critics have suggested paying more attention to social networks, material and territorial realities such as infrastructure and road networks, economic incentives, power dynamics, and, above all, the relations between all of them and the incumbent actors $(29,32,34,36-39)$. Doing so would entail discarding stark divisions between the sociotechnical system, the regime running it, and innovative niches, leading to a more holistic overview where different factors interlink $(29,32,34)$.

This article partakes in defining the sustainability transition process fuller by offering an approach that broadens the scope of the carbon lock-in theory (and by association, the Multi-Level Perspective) by combining it with the structuration model developed especially for analyzing national energy policy-making (55). Utilizing the 
(C) 2021. This manuscript version is made available under the CC-BY-NC-ND 4.0

license https://creativecommons.org/licenses/by-nc-nd/4.0/

https://doi.org/10.1016/j.eist.2019.10.006

structuration model makes it possible to examine the relations between enabling and restricting sides of prevailing practices and actors. As a consequence, this approach helps demonstrate that barriers are far from being absolute, but instead contain several possibilities and unforeseen consequences. Moreover, considering that a majority of sustainability transition literature has focused on developed, energy importing Western countries and on policy instrument diffusion instead of policy outcomes (39), case studies examining energy transition in different conditions are needed to fill a considerable research gap.

With the help of interviews with both Russian and non-Russian specialists, local newspaper material and key policy documents, this article seeks out what kind of constraining and enabling factors affect the possibilities for innovative niche solutions to gain ground and, in turn, influence the broader structures of a local energy system. The article begins by describing the background for the modernization efforts of the Arkhangelsk district heating system. Next, I present the data and methods utilized and discuss energy transition literature further, focusing on how the theory on carbon lockins and the structuration model may be combined. In what follows, the article elaborates on the results in order to offer a full overview of the present situation. I conclude by highlighting key issues that have the most potential of determining the direction of future development and by making some recommendations for both policy-makers and researchers in the field. By exploring the process of a sustainability transition within the district heating system, this article seeks to find out how do different types of carbon lock-ins intertwine and influence each other in a local context of rural settlements, and from what starting point might they be broken.

\subsection{Policy environment surrounding district heating modernization and renewables}

The Russian district heating system is the largest in the world, with its networks covering thousands of kilometers and consuming a third of the country's primary energy resources (40). It is remarkably exhaustive, supplying both buildings and industry, but at the same time it is characteristically inefficient. Russian boiler efficiency is around $75 \%$ (while the European and American average is 85-90\%), and 
(C) 2021. This manuscript version is made available under the CC-BY-NC-ND 4.0

license https://creativecommons.org/licenses/by-nc-nd/4.0/

https://doi.org/10.1016/j.eist.2019.10.006

the state has estimated that $30 \%$ of the system's infrastructure is in urgent need of repairs (41). The district heating system is fueled mostly by gas (66\%) and coal products $(21 \%)$ (42). The share of renewables (mostly biomass) in the heating supply has been minimal, a tenth of the share of coal (7), but their potential is significant. The World Bank estimated in 2014 that Russia's heat supply systems are among the most energy intensive sectors of the country (43). The energy saving potential of Arkhangelsk heat supply alone has been estimated as 865 tons per year (4). Plans for modernizing the district heating systems are compiled at the regional level and carried out in the municipalities mostly from the regional and municipal budgets, although federal resources are used for some priority projects and the requirements and initiative usually originate from the state level (44). Thus, the regional energy development can be seen as a direct continuation of the politics at the state-level.

Russia has included the modernization of the country's district heating system in its official targets for the coming decades, backed up by new legislation on heat and electricity $(41,43)$, which link the goal with better usage of the country's renewable resources. The overall goal for renewables in total energy production is currently at least $2.5 \%$ in the draft for "Energy Strategy of the Russian Federation Until 2035" (44). Moreover, the Russian government has stated that utilizing renewable energy resources more efficiently is a key factor in improving its global competitive advantage and developing the country's Arctic regions (45, 46). However, the actions of the Russian state have for long lacked the consistency and perseverance required for completing the current objectives for renewable energy usage (17). Even though developing the Arctic regions is high on the list of national priorities, the interest is targeted towards mega projects, not small-scale modernization $(14,15)$.

In addition, there is still a lot of deep-rooted suspicion in Moscow regarding sustainability transitions. Russia's ratification of the Paris agreement only happened four years after its signing, in autumn 2019, and concern that the agreement would harm the interests of the industry, especially those of oil and gas producers, is likely still strong $(49,50)$. The recent presidential decree on energy security lists the acceleration of global economic transition toward renewables as a challenge to Russian energy security. Prioritizing the interests of fossil fuel producers is thus likely to pose a considerable obstacle for renewable energy development in the country, although the 
(C) 2021. This manuscript version is made available under the CC-BY-NC-ND 4.0

license https://creativecommons.org/licenses/by-nc-nd/4.0/

https://doi.org/10.1016/j.eist.2019.10.006

same decree also mentions falling behind other countries in global energy trends as another challenge for the national energy security (50). It may be that at present, a major driver of developing renewable energy policies is the wish to prepare against possible losses caused by decreasing profits from hydrocarbon exports (51).

During the 2010s, plans have been made in the region of Arkhangelsk to follow the national direction of improving energy efficiency and energy security. Decreasing the region's strong dependence on coal and heavy oil imports by replacing part of them with local alternatives is a key step $(4,5,44)$. At the moment, $85 \%$ of the regional energy balance consists of imported fossil fuels (44). The region of Arkhangelsk has estimated that its energy saving potential is 865 tons of fuel per year from heating alone, and that altogether, 145,000 tons of imported fuel could be replaced with local, renewable energy sources (4).

In 2014, the Arkhangelsk Center for Energy Saving compiled the first regional long-term program for energy efficiency and local energy resources, named "The concept of local heat supply development in the Arkhangelsk region until 2030" (44). The official target is that by 2030, the share of alternative energy sources would increase to $44 \%$ and that of natural gas to $54 \%$, while the share of coal would decrease to just $2 \%$ and the use of diesel fuel would cease, meaning almost complete withdrawal from interregional fuel imports. Investments should come from both federal, regional, and municipal budgets as well as from the private sector in the form of public-private partnerships and investment programs. This far, regional modernization efforts have mostly consisted of dismantling outdated boilers and replacing them with ones running on biofuels (52).

\section{Material and methods}

Thirteen experts, eight Russian and five of other nationalities (see Table 1 for more details), were interviewed during 2016-2017 for this article about the overall prospects of renewable energy sources in Russia and specifically the future of biomass energy in the Arkhangelsk region. All had specialized in Russian forestry industry development or the national renewable energy development in general. The interviewees were selected partly using the snowball sampling method, which allows expanding an initially narrow 
(C) 2021. This manuscript version is made available under the CC-BY-NC-ND 4.0

license https://creativecommons.org/licenses/by-nc-nd/4.0/

https://doi.org/10.1016/j.eist.2019.10.006

network of contacts by asking interviewees to recommend people to contact. The method is apt for situations where it is difficult to find suitable contacts, as in the case of this study, but its limitations include the possible biases created by interviewing people who belong in the same network. To avoid this, I interviewed people representing various different sectors. However, local governmental officials could not be reached and were therefore left out of the study. The interviews lasted approximately an hour and were semi-structured around the themes of Arkhangelsk's development priorities, renewable energy support schemes, biomass projects in the region, and practical problems regarding both successes and failures. The objective was that the interviewees were free to determine which issues were more important to discuss than others.

To gain deeper understanding of the local conditions, the views expressed in the interviews were weighed against the background of news articles from two regional newspapers and regional renewable energy policy documents. The newspapers Arkhangelsk and Business Class were selected on the basis of their circulation and coverage of the subject of renewable energy during the years 2013 to 2017 . Using the Russian media database Integrum, the newspapers were searched for articles containing one or more of the following terms: биомаск* (biomass), биоэнергетик* (bioenergy), биотоплив* (biofuel), and возобновл* (renewable). Altogether 49 hits, where reasons to invest in renewables and barriers on their way were discussed, were chosen for further analysis. The risk with using media materials such as local newspapers is the uncertainty of whether their reports depict the reality from a biased point of view. To alleviate this problem, information about the actions of the federal and regional governments were retrieved directly from the policy documents (as seen in the section 1.1). Unlike policy documents and media material, up-to-date reports regarding Russian renewable energy development or municipal heating are scarce and therefore this material was not included in the analysis.

The results from interviews and newspapers were arranged into eight thematic groups according to the categories derived on the basis of the theory on carbon lock-ins and the structuration model: the constricting and enabling sides of a resourcegeographical, institutional, financial, and behavioral dimension. The combining of the two approaches is presented in more detail in Figure 1 of section 3.1. Following the 
(C) 2021. This manuscript version is made available under the CC-BY-NC-ND 4.0

license https://creativecommons.org/licenses/by-nc-nd/4.0/

https://doi.org/10.1016/j.eist.2019.10.006

principles of content analysis, after collecting and arranging all the data it was possible to condense similar results together and delete some views that were clearly more particular in order to create a cohesive overview. These results are presented in the Appendix in Table 2. The results could then be analyzed against the theoretical background of the research.

The article relies primarily on the interviews, while policy documents give context to the results. This is bound to pose some limitations to the study, since the results may have some bias as most data is based on personal experiences and opinions. For example, Russian and other nationalities tend to emphasize different kinds of factors in their estimations. However, energy models and programs have their own biases as well, as they often assume that the most rational choice will prevail. In practice, this is often not the case (53). Therefore, since this study is interested in both the successful and unsuccessful projects and policies, expert interviews were preferred due to the possibilities for hypothesizing they offered.

\section{Theory}

\subsection{Carbon lock-in theory applied to the structuration model}

Both the carbon lock-in theory and the structuration model ultimately draw on structuration theory $(17,54)$ and thus they are ontologically compatible. The literature on carbon lock-ins categorizes the lock-ins in a more or less detailed manner, but for this study, issues pertaining technological-infrastructural, institutional, and behavioral lock-ins came up most frequently, and were therefore chosen for further analysis. The technological-infrastructural lock-in encompasses infrastructure, urban elements, and logistics linked to extracting, storing, and transporting energy. Institutional lock-in refers to the connecting networks, dependency, and power accumulated in the process of transporting and using energy. All these relations carry a great amount of vested interest in the continuance of current economic and social structures (23). Political commitment to the existing path is usually so strong that institutional factors are more likely than technological-infrastructural ones to reinforce current practices into norms, and with greater implications (55). Finally, the behavioral lock-in refers to the way in which the current energy system is deeply embedded in the social and habitual practices, which 
(C) 2021. This manuscript version is made available under the CC-BY-NC-ND 4.0

license https://creativecommons.org/licenses/by-nc-nd/4.0/

https://doi.org/10.1016/j.eist.2019.10.006

consist of routines and norms that have evolved together with local institutions, infrastructure, and policies (23). Put together, different lock-ins reinforce inertia and create dynamic, collective obstacles that stand in the way of developing low carbon alternatives.

The structuration model aims to concretize the structural conditions in which the actors interact and make choices by presenting analytical categories for these conditions $(56,57)$. These conditions or 'dimensions' are both material and social, and both enable and constrain the actors. In the original model, the categories are resource geographic, financial, institutional, and ecological dimension (56). The multilevel perspective has been previously combined with the structuration model in energy transition studies (58), where it was noted that with the help of both, it is possible to comprehend better the multidimensional nature of the structures surrounding energy transitions. I combine the model with the carbon lock-in theory to reach a more comprehensive view of energy transition barriers. In addition, applying the structuration model to the study on niches in energy transition processes contributes to the research on renewable and sustainable energy by incorporating not only various barriers, but also enabling factors into the overall picture.

In many respects, the dimensions of the structuration model (geographic, institutional, financial, and ecological) are compatible with the three basic types of carbon lock-in: technological-infrastructural, institutional, and behavioral (23-25). Firstly, both approaches understand the geographic or technological-infrastructural resource factor as encompassing all relevant issues. Similarly to the technologicalinfrastructural lock-in, the geographic resource dimension covers all issues along the energy production line, from the ground or forest all the way to homes, establishments, and industries, and further to the implications of energy use and other actors involved. Issues related to infrastructure are also essential, as they deal with transporting, storing, and distributing energy (57). I decided to place energy security issues to this category, as they seem not to be linked to renewables at the institutional level in the same way as energy efficiency issues. In my empirical analysis, I combine all the factors associated with the material reality surrounding renewable energy development under the term "geographic resource and infrastructure." 
(C) 2021. This manuscript version is made available under the CC-BY-NC-ND 4.0

license https://creativecommons.org/licenses/by-nc-nd/4.0/

https://doi.org/10.1016/j.eist.2019.10.006

The literature on carbon lock-in puts institutional and financial factors together, while the structuration model separates them. In the world of energy policymaking, they are often intertwined - financial decisions are shaped by decisions made at the institutional level, and financial conditions limit the decisions that are possible to be made. However, as the vast majority of interview and media data focuses on financial and institutional factors, they have been separated here for the sake of clarity, with a few overlapping cases. Furthermore, the financial dimension is at least as manifold as the geographic resource one. Even though renewable energy projects differ in many aspects from those utilizing fossil fuels, the amount of investment needed especially in the beginning is significant. In my analysis, I consider not only financial incentives, support schemes, and constraints but also issues such as pricing, billing systems, and possible economic reforms. A larger number of actors is involved in the financial structures. These actors range from the public to the private sphere, and from smallscale investments such as those of local sawmills to large-scale ones, like those commissioned by state-owned energy companies often in the context of national programs.

As for institutions, they come in many shapes and forms, ranging from informal to formal ones, from those with unwritten rules to official institutions. In Russia, the emphasized state control over institutions and civil society generally results in the weakening of these institutions and the emergence of their substitutes, leading to even more centralized governance. Simply put, attempts to engage as few people as possible in decision-making increases the risk of unexpected troubles and even systematic breakdowns, since the rulers' connection to popular opinion is bound to be rather weak (37). In the empirical results, these circumstances demonstrate themselves in the form of politically motivated energy investments, inefficient or inadequate regulation, gaps between plans and their implementation, and accumulations of power and money.

When organizing the results of the interviews, I replaced the ecological dimension with a behavioral one. This decision is not just to stay in line with the categories of the carbon lock-in theory. Studies conducted on Russian energy policymaking documents have shown that even in the policy-making sphere, ecological aims are often limited to reducing waste and emissions instead of addressing broader issues 
(C) 2021. This manuscript version is made available under the CC-BY-NC-ND 4.0

license https://creativecommons.org/licenses/by-nc-nd/4.0/

https://doi.org/10.1016/j.eist.2019.10.006

such as climate change $(59,60)$. Indeed, Aalto et al. (56) point out that the ecological dimension does partly run against the geographic resource and financial dimensions, making actors interested in the traditional viewpoint on energy not likely to address ecological issues. Therefore, I argue that replacing the ecological restraining and enabling factors with the behavioral ones helps to explain the absence of ecological discourse from the interview and media data. For example, the behavioral lock-in becomes visible in the perceived lack of motivation to invest in projects which are not believed to attract notable federal support in the near future. In general, it is not believed that ecological factors could play a role in the Russian policy-making field due to the prevailing state of mind focusing more on energy supply than energy efficiency, and thus interviewees do not consider them either. Instead, experts view renewable energy solutions according to what they perceive as "sensible" or "desired" within the frame of more general development goals.

In the end, we have four dimensions: the geographic-infrastructural, the institutional, the financial, and the behavioral dimension. In what follows, I examine the research results under these categories in order to explore the enabling and constraining structures affecting the development of biomass energy in Arkhangelsk.

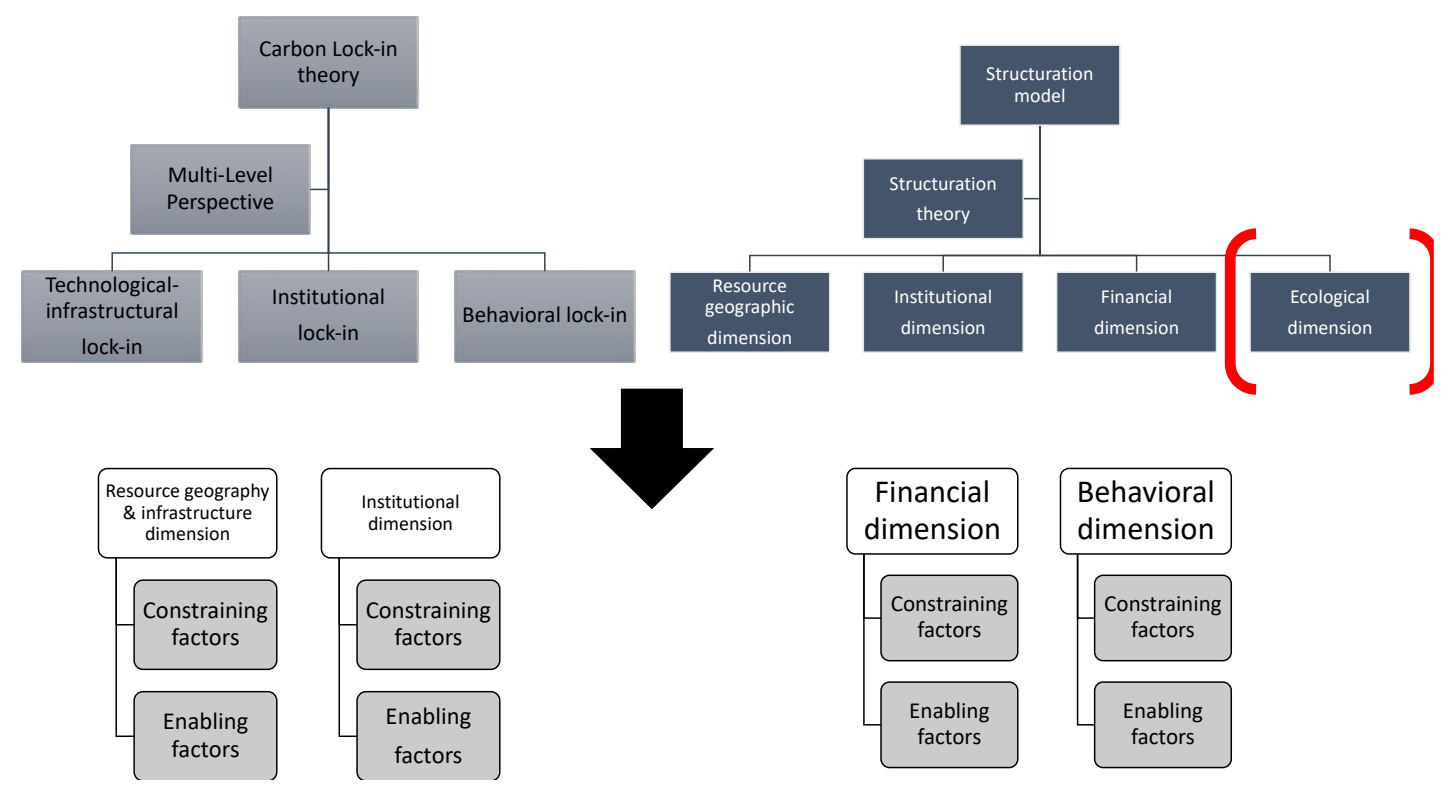

Figure 1. Combining the theory on carbon lock-ins with the structuration model. 


\section{Results}

\subsection{Constraining and enabling factors in the geographic-infrastructural dimension}

In accordance with the Soviet tradition of planned economy, the heat network was originally built as very centralized, meaning that the infrastructure of a whole town was typically bundled together, and power plants, factories, schools, hospitals, and residential buildings were all linked into the same district heating system (28). Still today, in several smaller settlements of Arkhangelsk, the same system obliges pulp and paper mills to provide energy not only for themselves but also to surrounding residential blocks. To fulfill this obligation, the mills must ensure that they always have extra power capacity. This is a goal most simply achieved by stocking coal, and, as a result, one expert reported, the motivation to experiment with new technologies and methods decreases. However, comparing Russia with the heating reforms completed in other previously centrally planned countries of Poland, Romania and Slovakia shows that under the right circumstances, a centralized district heating network not only impedes modernization but may also expedite it (61). It has been estimated that already between 2025-2035, most of the worn-out thermal power plants must be upgraded or replaced (62). While this is a huge task, it also creates the possibility to invest in a completely new energy system. Since biomass could still utilize mainly the same heat network as fossil fuels, the disruption to the existing system architecture could be minimized, making the reforms more likely to succeed (25). In other words, a successful modernization project could establish a 'positive lock-in' which would then help stabilize the status of renewable energy in the Russian energy palette.

Other parts of the local energy delivery system are in need of repair as well. Russia's perpetual problem, poor roads, repeatedly came up in the interviews with both Russian and non-Russian specialists. Together with the long thaw of the Russian North, the bad condition of (forest) roads greatly affects the security of supply, making energy from biomass seem like a risky option during the long heating season. "The local aspect was especially important, because at the end of the day, transport costs define what kind of a project will be implemented" (Table 1, \#11), emphasized one interviewee. Among 
(C) 2021. This manuscript version is made available under the CC-BY-NC-ND 4.0

license https://creativecommons.org/licenses/by-nc-nd/4.0/

https://doi.org/10.1016/j.eist.2019.10.006

other problems mentioned was the fact that the transportation of renewables is not subsidized, unlike that of fossil fuels. Another expert pointed out that "It's actually the biggest problem to move pellets 500 kilometers, it's much more expensive than to move coal 5000 kilometers" (Table 1, \#1).

To complicate things further, Arkhangelsk region is not, despite its vast forest resources (78\% of the land (9)), equally densely covered with forest in all parts of the region. Thus, much more efficient management would be needed in order to create a competitive bioenergy market. On the other hand, the uneven quality of wood also means that large quantities go underutilized. The potential for using surplus wood for energy is, as one Finnish forestry expert put it, "huge" (Table 1, \#10). Technical advancements and new sources of biomass fuel are being envisioned, by the more optimistic interviewees, as a key component accelerating the share of renewables in the future, as they become cheaper and more attractive for everyone to use. The most pressing problem is that imported technology is, for the time being, very expensive in Russia, and domestic solutions are not being developed enough.

\subsection{Constraining and enabling factors in the institutional dimension}

When it comes to legislation and renewable energy use, it is clear from the literature $(10,11)$ and the interviews that the persistent problem is not the amount or quality of legislation or regulation but implementing new measures. Only one interviewed specialist argued that the development of renewable energy sources would still require more specific legislation, while others directed the discussion toward law implementation and enforcement. Foreign expert working in forestry (Table 1, \#10) regarded legislation as rather unpredictable and prone to sudden changes, while several Russian interviewees mention that reducing legislation would help new methods to gain ground. This is the case with wood waste, of which a part must be dumped into wastewater sludge instead of burning it for fuel. Target programs face similar problems. The Russian Ministry of Energy itself admitted in 2016 that the capacity-based renewable energy support scheme, launched in 2013, should not be expected to add more than $0.3 \%$ to the share of renewables in electricity production (then $0.67 \%$ ). The target of the program was to increase the share of renewables to $4.5 \%$ (62). Problems with implementation, management, and accountability arise in various shapes and 
(C) 2021. This manuscript version is made available under the CC-BY-NC-ND 4.0

license https://creativecommons.org/licenses/by-nc-nd/4.0/

https://doi.org/10.1016/j.eist.2019.10.006

forms. A non-Russian bioenergy specialist working in Moscow complained that when a decision is should be properly followed in the regions, "nowhere it reads who specifically has to do all this, therefore these requirements are meaningless" (Table 1, \#9). As a result, officials compiling target programs often struggle to ensure that Moscow's intentions are carried through in the regions, national strategies are not "processed" locally until their completion and thus remain hollow (Table 1, \#2). An anecdote reported in the media tells of a new boiler which was bought and brought to a remote village but then, for no apparent reason, left uninstalled in the open air (1).

The lack of a Forest Ministry is mentioned a few times. At the moment, forest issues are collectively managed by the Ministry of Natural Resources and the Environment and the Ministry of Industry and Trade, and at the regional level by the local ministries. This leads to a situation where, according to one expert, the vast forests of the country are simultaneously under a complex bureaucratic rule and yet largely not managed at all. They are used in a very haphazard manner, wherever it is easiest to cut through, letting a large part of the wood waste "just rotting away" (Table 1, \#9). Once again, accessibility and lack of decent roads also add to the problem. In the case of renewable energy, the lack of middlemen and underdeveloped networks means that there is little help for new entrepreneurs with the red tape involved in securing the available state support.

Cases such as these demonstrate the gaps and incongruences between the national policy-making level and the regional realities. However, including regional needs more comprehensively in the decision-making process would entail the risk of letting parts of the current status quo of domestic energy politics crumble. In other words, granting regional governments more responsibility for their energy policies would likely lead to more freedom of action regarding their use of energy deposits. The long legacy of centralized planning and ruling has also signified fixed resource flows, accumulations of subsidy money and strong interest groups clustered around them. Receiving subsidies from the state or the regional government for buying fuel from another region creates a chain of local actors, all used to receive their share and not willing to give it up. As the Head of the energy program of a Russian environmental organization summed up, "the cash flow is very stuck to the existing players" (Table 1, \#8). In particular, non-Russian specialists argued that the business and political actors have different motives, a 
(C) 2021. This manuscript version is made available under the CC-BY-NC-ND 4.0

license https://creativecommons.org/licenses/by-nc-nd/4.0/

https://doi.org/10.1016/j.eist.2019.10.006

situation which makes carrying out even the simplest business plans surprisingly difficult. As a result, "many projects once started are never finished, while the money reserved for them is always spent" (Table 1, \#10). Some fossil fuel producers are more difficult to compete against than others, not only because some fuels are subsidized more but because some hold more political leverage than others. While natural gas is clearly in its own rank due to its high availability and low price, coal mining employs significantly more people than the heavy oil industry, granting it more political influence than diesel fuel producers. Thus, diesel fuel is at the moment a much more equal adversary for renewable energy resources.

New actors in the field are bound to have far less extensive networks and lobbying power, and so people and organizations pursuing policies supporting renewable energy source usage lack the resources to create a lasting impact. At the moment, most of their work consists of gathering and spreading information. For example, there is related research being conducted at the Northern (Arctic) Federal University of Arkhangelsk, but it is mainly in the form of projects of three or four years and has limited funding, leaving little room for extensive projects. Lack of specialists was named a couple of times as a constraining factor. None of the experts interviewed believed in Russia developing new technologies or products in the field of renewable energy on its own. Another part of the problem is the lack of permanent civil servants in Russian local governance. As they are replaced after each elections, even projects that have started are at great risk of never being completed.

On the other hand, the dominant role of Gazprom and its exhaustive pipeline network might also create a need for both the company and its customers to find more flexible alternatives, meaning that its relationship with regional customers might not be as straightforward as often thought. For example, it was reported in March 2016 that building new gas infrastructure in the Arkhangelsk region had been halted because of unpaid consumer debts (2). In addition, despite the low price of gas, a consultant working in Arkhangelsk reported that local sawmills are not satisfied with Gazprom's billing policy.

"The problem in Russia is that basically Gasprom is the one and only, and it's not that easy to deal with them because the type of agreement they like to have is... it's called "take it or pay it". If you say in the beginning that you are going to be 
(C) 2021. This manuscript version is made available under the CC-BY-NC-ND 4.0

license https://creativecommons.org/licenses/by-nc-nd/4.0/

https://doi.org/10.1016/j.eist.2019.10.006

using 50 million cubic meters of natural gas, then whatever you use, you have to anyway pay for the 50 million" (Table 1, \#4).

The principle has been that companies pay for a fixed amount of gas irrespective of the amount they actually consume. This policy may cause worry, for example, to entrepreneurs that are unsure of the productivity of their following year. Hence, having more than one energy supplier may appear as a more secure option. At the moment, some sawmills looking for alternatives choose renewable energy while others opt for coal. In the larger context, the influence of Gazprom and its lobbying power should of course not be overlooked.

At the institutional level, niches currently arise mainly as a result of the current legislation, which links energy efficiency with the use of renewables. Since its deployment, the amount of related target programs, declarations and regional programs has increased twofold, the most detailed being the Concept for developing local heating, which focuses on optimizing both the budget and energy efficiency with the help of local renewable resources $(44,45)$. As noted, specialists interviewed mostly agree that the legal framework for modernizing the energy complex is both sufficient and appropriate, although not yet likely to attract private investors to the field.

\subsection{Constraining and enabling factors in the financial dimension}

Most specialists interviewed agreed that the main constraint in modernizing the district heating system with the help of biomass is the lack of financing tools, investors and, ultimately, actual money. Due to their high initial costs and the underdeveloped state of the markets, renewable energy installments would need all the possible support to succeed. However, the problem is that even when switching to local energy sources saves money rather than gains more. As a bioenergy expert stationed in Arkhangelsk put it, "You save, probably, but you don't feel the money in your hands" (Table 1, \#4). In addition, currently the whole process of transforming wood into energy, with all the logistical costs, renders the savings null. The state support available at the moment, at least for other than priority projects, is mainly in the form of tax reductions, cheaper raw material, or other types of allowances instead of more concrete subsidies.

The municipalities of Arkhangelsk would make natural financiers, but with the low heat tariffs, they are struggling to maintain even the existing energy infrastructure. 
(C) 2021. This manuscript version is made available under the CC-BY-NC-ND 4.0

license https://creativecommons.org/licenses/by-nc-nd/4.0/

https://doi.org/10.1016/j.eist.2019.10.006

Thus, most funds from the current energy efficiency program go into patching up the current installations instead of putting up new ones in the region (64). According to the interviews, the same applies to many local enterprises. The expert opinions differ as to whether it would be possible to raise the price of heat, even temporarily, to help cover the costs of modernizing boilers. Especially Finnish experts saw a heat reform as a key prerequisite for any modernizing of the energy complex. Nevertheless, most experts agree that the residents of small settlements could not afford higher tariffs without government support.

The expense of biomass energy use might decrease as new technologies allow drying wood chips and bark more efficiently, notably diminishing the cost of wood processing. If such technologies become more widely available and companies are motivated to exploit their own residuals, the low price of wood chips, for example, may compete even with the subsidized price of fossil fuels. In addition, the price of biomass has remained rather stable compared to fossil fuels.

Public-private partnerships have been tested in several cases in the Arkhangelsk region. They are often found to be an efficient way to evade some of the trickiest financial problems facing biomass energy. The cases reported in the news articles usually involve joint energy companies established between a small town and a local sawmill. In one such case, the municipal heating boilers were replaced with biomass burning ones, utilizing the waste wood produced in the sawmill and reducing the number of waste dumps (2). Such joint ventures seem to avoid the usual constrictions better by using sawmills' own residuals instead of buying them from outside sources. Second, splitting the cost of investments means that the sawmill invests only in the new boiler and the municipality in the heating network. Sawmills may also be able to afford to take outside loans better than municipalities can. It seems that the local industries might provide renewable energy sources the types of niches that small-scale energy transition development requires by offering viable market opportunities.

Initially they (Sawmill N:o 25) started producing pellets, and in the second step, they started building and operating the relatively small capacity boilers running with these pellets. To supply heat for the small settlements. This is probably the most interesting success story in the sawmill industry (Table 1, \#4). 
(C) 2021. This manuscript version is made available under the CC-BY-NC-ND 4.0 license https://creativecommons.org/licenses/by-nc-nd/4.0/ https://doi.org/10.1016/j.eist.2019.10.006

\subsection{Constraining and enabling factors in the behavioral dimension}

In general, the interviewees held contradictory views regarding the motivation of regional and municipal leaders to improve the energy security, energy efficiency of residential heating, and how the relationship between increased energy efficiency and renewable energy was understood in the first place. In particular, interviewees working in business stated that the governing bodies mainly invest in high-profile projects that may bring about profits quickly and thus favor project proposals from influential companies. In addition, projects that develop or utilize technologically more advanced fuels such as liquid biofuels may seem more attractive since their world market price is high, even though their markets are very small. In other words, the everyday problems of regional heating needs are not believed to be a priority for bigger investors.

Several experts mentioned that many bigger projects, especially those granted a priority status, are often based on political motives rather than practical ones. A Finnish forestry expert emphasized that the concept of social responsibility affects expectations laid for a new project. After a project has been given funding, the company realizes it is expected to take part in the social development of the surrounding city or region. As bigger actors may be more easily coaxed into directing the development of the region as desired, they also appear as more interesting targets for the state to support. In particular, non-Russian but also Russian specialists mentioned the problems arising from these arrangements. Local actors such as forest companies are left unsure as to why some projects are deemed a priority, entitling them to subsidies and tax reductions, while others are not. As a result, the investment climate is very uncertain.

Non-Russian interviewees, in particular, emphasized the role of Russian attitudes and ideas. Although residents of small Arkhangelsk settlements are few in number and relatively poor, and thus have little political leverage, they wield certain political power. They are part of an old social contract that may even be viewed as the core of the Russian social order - the legacy of heavily subsidized heat (65). Several interviewees began describing the current circumstances with a simple phrase: "Russia is a land of oil and gas." (Table 1, \#7) This statement is not only a description of the present economic situation, but also a state of mind. Living in an "energy superpower" like Russia implies that the abundance of energy should be granted, redeeming the shortages marking the 1980s and 1990s (28, 65). Similarly, a frequently mentioned 
(C) 2021. This manuscript version is made available under the CC-BY-NC-ND 4.0

license https://creativecommons.org/licenses/by-nc-nd/4.0/

https://doi.org/10.1016/j.eist.2019.10.006

notion was the vastness of the country's resources, both renewable and fossil, making wasting them not seem like an issue. As the gas distribution network of the parastatal gas company Gazprom is now extending its reach to the furthest corners of the nation in accordance with the company's gazifikatsiia (gasification) program, it does not seem that the state would be ready to loosen its grip on the power associated with energy deliveries. On the contrary, the energy-superpower discourse has only gained more significance in the national context during the 2000s (65).

The role of motivation and mindset also arises frequently as an enabling factor. A non-Russian bioenergy consultant (Table 1, \#9) remarked that since accidents in energy transportation and storage are bound to become more common in the near future, they might also provide the decisive push needed to increase the motivation for exhaustive repairs. Currently, the Arkhangelsk region would prefer a more diverse and local heating supply than the gas and coal deliveries can offer, at least at the level of official statements $(4,44)$. This wish was the most often mentioned enabling factor supporting biomass energy. Improving the energy security of a settlement could strengthen local industries while keeping the subsidies within the region, instead of sending them away. The utilization of local renewable resources is viewed as a costefficient way to achieve these goals. Furthermore, as a side effect new practices would help get rid of another problem regarding raw material flows - waste dumps scattered around the region. Some Russian specialists, while none of the non-Russian ones, saw the government's attitudes toward biomass energy also as an encouraging factor. Some mentioned the government as "not unwilling" (Table 1, \#6) to give up on coal and heavy oil, while others claimed that especially biomass has raised genuine interest in the Kremlin. However, interviewees holding these opinions also noted or implied that it might take time before the benevolent stance would have an effect. As for regional governments, one interviewee working in saw mill business concluded: "They are talking. I'm not sure they understand what they are talking but they are definitely talking about it" (Table 1, \#6).

\section{Conclusion and recommendations: Working with and against the prevailing lock-ins}


(C) 2021. This manuscript version is made available under the CC-BY-NC-ND 4.0

license https://creativecommons.org/licenses/by-nc-nd/4.0/

https://doi.org/10.1016/j.eist.2019.10.006

Against the current background, the potential of niches to gain ground in Russia may seem rather faint and the current conditions unyielding. On the basis of the results and literature on energy transition outcomes (for example 6, 66), it can be stated that consistent and informed state support would be essential so that new technologies and solutions could reach regional actors in remote areas dependent on fuel imports. However, even sustained government support is unlikely to make a difference if the product is not profitable in the current market situation. Instead, approaches that start by only changing a part of the prevailing system and attempt to align themselves with the old infrastructure are more likely to gain success than those aiming to replace the whole system. However, while being able to decrease the inertia of technological-institutional lock-ins, solutions relying on continuity are also prone to performance trade-offs. An example of this phenomenon in the region can be found among the power plants and sawmills that install new technology on top of an old energy distribution and billing system, or even keep utilizing fossil fuels for some consumers.

As for fossil fuel imports, their logistics and customers, decisions made over time in the geographic-infrastructural dimension are being reinforced by the institutional, financial, and behavioral dimensions of the regime. Together they create and support the existing carbon lock-in, the resilience of which is partly explained by the fact that its existence also serves the stability of the regime itself. The intertwined lock-ins become visible in the way in which the municipal heating networks bundle power plants, sawmills, pipelines, residential buildings, and establishments together and link them with the governing bodies and their policies, each lock-in reinforcing one another. The results confirm that, as is common for all carbon lock-ins, breaking a technological lock-in is more of a practical question, while the institutional and behavioral lock-ins cause more complicated problems. Mismanaged or undermanaged resources, projects, and funds lead to a situation where, even though the spending of allocated money may follow fixed routes, the outcome of a project is highly uncertain. Here, the financial and institutional lock-ins again intertwine and support each other.

The lack of institutions or actors that would act as direct link between federal policies and regional politics makes it more difficult to direct the existing investments properly and ensure the implementation of intended measures. This kind of ambiguity and lack of responsible actors create room for nontransparent practices and 
(C) 2021. This manuscript version is made available under the CC-BY-NC-ND 4.0

license https://creativecommons.org/licenses/by-nc-nd/4.0/

https://doi.org/10.1016/j.eist.2019.10.006

corruption, and the lack of money weakens the regional institutions' ability to react. As a result, the distances between energy resources, energy producers, and the customers grow even longer and more expensive. The behavioral lock-in feeds further into the dilemma by questioning the need for alternatives, as manifested in several experts' sentiment of "what's the point?" Even in their inefficiency, established practices create norms that the current regime may utilize in assuring its stability. Such a norm is, for example, the social contract of subsidized heat, which binds together the state, local energy companies, sawmills, institutions, and the residents. On the other hand, as examples from other post-Socialist countries demonstrate (61), the rigid and centralized structure of a district heating network would also allow an efficient and centralized reform. In other words, it is possible that all three lock-ins could, in particular cases, be undone together as well.

While the connections between actors working with fossil fuel usage are stable, fixed, and unquestioned, the actors dealing with renewables have to form new connections at the beginning of each project. The isolated status of renewable energy actors among the strong networks of subsidized fossil fuels is the most pressing issue in the way of the field's further development. Actors interested in replacing fossil fuels with biomass in power plants, selling their wood waste for energy production, or starting completely new businesses must navigate through the current obstacles largely by themselves, meaning that a lot of resources and energy are spent on dealing with individual tasks and problems. Building new networks is not an easy feat under the current conditions, where state investments are perceived to be often directed by political motives or sheer corruption (money disappearing to powerful actors in the region). Therefore, it is unlikely that energy transition would happen in the Russian peripheries with the help of aspiring outsider actors or consumer choices, as is often the case in Western Europe, for example.

In order to overcome the carbon lock-ins and to profit from opportunities of the niche level, actors working for increasing biomass usage for energy especially in remote, isolated areas should create more direct linkages between resource streams and energy production. It is likely that a more systematic approach would help alleviate some of the problems caused by the broader landscape as well - i.e. poor roads, thaw, and the resulting expensive logistics. In other words, the solution for local stakeholders 
(C) 2021. This manuscript version is made available under the CC-BY-NC-ND 4.0

license https://creativecommons.org/licenses/by-nc-nd/4.0/

https://doi.org/10.1016/j.eist.2019.10.006

in politics and business for untying this knot lies in clustering the development efforts of small communities in a centralized manner so that the resources of each become more accessible to others. Projects that have formed clusters with already established industries and renewable energy projects - such as the public-private cooperation between saw mills and municipalities - are the ones developed the furthest in the Arkhangelsk region. The fact that regional legislation already supports the use of renewables might also help with these endeavours, especially if the relations between the regional administration and businesses are good. The approach of forming clusters was also recommended for Arctic communities in the report published by the Fulbright Arctic Initiative Energy Group (67).

Research should support these aspirations by paying more attention to the social part of socio-technical transitions. Examining the interactions and linkages between incumbent regimes and niche players instead of focusing on renewable technologies as a challenging or disruptive force would bring new understanding about energy transitions. Viewing local processes as a part of the wider continuum of carbon lock-in mechanisms helps to understand that even though renewable energy actors may be isolated, their issues and choices are far from unique. A more holistic approach is the only way to comprehend the complicated bundles hampering renewable energy development in remote fossil fuel importing regions, and thus the only way to produce meaningful results.

\section{Acknowledgements}

The author wishes to thank Dr. Veli-Pekka Tynkkynen and Dr. Daria Gritsenko for their comments and advice with the article.

\section{List of references}

[1] Emelyanova, D., $9^{\text {th }}$ August 2014. Реформа самоутепления. Business Class.

[2] Emelyanova D., 7th March 2016. Андрей Поташев: «Проблем хватает, но тренд позитивный», Business Class.

[3] The Federation of Finnish Technology Industries (Finpro), 2014. Energy Efficiency in Russia. 
(C) 2021. This manuscript version is made available under the CC-BY-NC-ND 4.0 license https://creativecommons.org/licenses/by-nc-nd/4.0/ https://doi.org/10.1016/j.eist.2019.10.006

[4] Arkhangelsk region, 2010b. О утверждении долгосрочной целевой программы Архангельской области "Энергосбережение и повышение энергетической эффективности в Архангельской области на 2010 - 2020 годы" и о мерах по её реализации, Government of the Arkhangelsk region 27.07 2010, 210-pp, available at: http://www.aoresc.ru/files/program_arh_2013_04_02.pdf (accessed 4.6 2019).

[5] Arkhangelsk region, 2013. Об утверждении государственной программы Архангельской области «Развитие энергетики и жилищно-коммунального хозяйства Архангельской области (2014 - 2024 годы)» (On approval of the state program of the Arkhangelsk region "Development of energy and housing and communal services of the Arkhangelsk region (2014 - 2024)", Government of the Arkhangelsk region 15.10 2013, available at: http://docs.cntd.ru/document/462608457 (accessed 3.6 2019).

[6] Boute, A., Seliverstov, S., 2018. A tortuous path to efficiency and innovation in heat supply. In: Zillman, D., Godden, L., Paddock, L., Roggenkamp, M. (eds.), Innovation in energy law and technology: Dynamic solutions for energy transitions, Oxford Scholarship Online: May 2018.

[7] International Renewable Energy Agency (IRENA), April 2017. REMAP 2030: Renewable energy prospects for the Russian Federation. Available at: https://www.irena.org/-

/media/Files/IRENA/Agency/Publication/2017/Apr/IRENA_REmap_Russia_paper_201 7.pdf\#page $=85$ (accessed 26.6 2019)

[8] Russian Energy Agency (Россииское Энергетическое Агентство), 2012. Биоэнергетика России в XXI веке (Russian bioenergy in the 21st century), Moscow.

[9] The Ministry of Natural Resources and Forestry of the Arkhangelsk Region, 2013. The forestry complex of the Arkhangelsk region is a strategic supplier of energy resources. Presentation available at: http://www.myshared.ru/slide/933864/ (accessed $4.62019)$

[10] Berdin, V.Kh., Kokorin, A.O., Yulkin, G.M., Yulkin, M.A., 2017. Renewable energy in isolated settlements of the Russian Arctic. WWF, Moscow.

[11] Pristupa A, Mol A., 2015. Renewable energy in Russia: The take off in solid bioenergy? Renewable and Sustainable Energy Reviews 50, 315-24.

[12] Korppoo, A, Korobova, N., 2012. Modernizing residential heating in Russia: Enduse practices, legal developments, and future prospects. Energy Policy 42, 213-20.

[13] Lanshina, T., Laitner, J. A., Potashnikov, V. Y., Barinova, V. A, 2018. The slow expansion of renewable energy in Russia: Competitiveness and regulation issues, Energy Policy 120, 600-609. 
(C) 2021. This manuscript version is made available under the CC-BY-NC-ND 4.0 license https://creativecommons.org/licenses/by-nc-nd/4.0/ https://doi.org/10.1016/j.eist.2019.10.006

[14] Kinossian, N., 2013. Stuck in transition: Russian regional planning policy between spatial polarization and equalization, Eurasian Geography and Economics 54 (5-6), 611629.

[15] Orttung, R. W., 2015. Promoting sustainability in Russia's Arctic - Integrating local, regional, federal, and corporate interests. In: The challenges for Russia's politicized economic system, by Susanne Oxenstierna (ed.), Routledge: Oxon.

[16] Jørgensen, U., 2012. Mapping and navigating transitions - The multi-level perspective compared with arenas of development. Research Policy 41 (6), 996-1010.

[17] Geels, F., 2012. A socio-technical analysis of low-carbon transitions: introducing the multi-level perspective into transport studies. Journal of Transport Geography 24, 471-82.

[18] Scrase I., Smith, A., 2009. The non-politics of managing low carbon sociotechnical transitions. Environmental Politics 18 (5): 707-26.

[19] Geels, F., 2002. Technological transitions as evolutionary reconfiguration processes: a multi-level perspective and a case-study. Research Policy 31 (8-9), 1257 74.

[20] Smith, A. 2006. Niche-based approaches to sustainable development: radical activists versus strategic managers. In: Bauknecht D, Kemp R, Voss JP, Sustainability and Reflexive Governance, Edward Elgar, Camberley; 2006.

[21] Smith, A., 2007. Translating sustainabilities between green niches and sociotechnical. Technology Analysis \& Strategic Management 19 (4), 427-450.

[22] Rotmans, J., Kemp, R., Van Asselt, M., 2001. More evolution than revolution: transition management in public policy. Foresight 3(1), 15-31.

[23] Seto, K., Davis, S., Mitchell, R., Stokes, E., Unruh, G., Ürge-Vorsatz, D., 2016. Carbon lock-in: Types, causes, and policy implications. Annual Review of Environment and Resources 41, 425-52.

[24] Unruh, G., 2000. Understanding carbon lock-in. Energy Policy 28(12), 817-30.

[25] Unruh, G., 2002. Escaping carbon lock-in. Energy Policy 30(4), 317-25.

[26] Goldthau, A., Sovacool, B., 2012. The uniqueness of the energy security, justice and governance problem. Energy Policy 41, 232-40.

[27] Sidortsov, R., 2012. Creating Arctic carbon lock-in: Case study of new oil development in the South Kara Sea, Carbon and Climate Law Review 6(1), 3-12.

[28] Collier, S., 2011. Post-Soviet social: Neoliberalism, social modernity, biopolitics. Princeton University Press: Princeton and Oxford. 
(C) 2021. This manuscript version is made available under the CC-BY-NC-ND 4.0 license https://creativecommons.org/licenses/by-nc-nd/4.0/ https://doi.org/10.1016/j.eist.2019.10.006

[29] Sorrell, S., 2018. Explaining sociotechnical transitions: A critical realist perspective, Research Policy 47 (7), 1267-1282.

[30] Kooij, H-J., Lagendijk, A., Oteman, M., 2018. Who beats the Dutch tax regime? Tracing 20 years of niche-regime interactions on collective solar PV production in the Netherlands, Sustainability 10 (8)

[31] Berggren, C., Magnusson, T., Sushandoyo, D., 2015. Transition pathways revisited: Established firms as multi-level actors in the heavy vehicle industry, Research Policy 44, 1017-1028.

[32] Carrosio, G., Scotti, I., 2019. The 'patchy' spread of renewables: A socio-territorial perspective on the energy transition process, Energy Policy 129, 684-692.

[33] Geels, F., 2014. Regime resistance against low-carbon transitions: Introducing politics and power into the multi-level perspective. Theory, Culture \& Society 31(5), 21-40.

[34] Buschmann, P., Oels, A., January 2019. The overlooked role of discourse in breaking carbon lock-in: The case of the German energy transition, WIREs Climate Change 10 (3).

[35] de Gooyert, V., Rouwette, E., van Kranenburg, H., Freeman, E., van Breen, H., October 2016. Sustainability transition dynamics: Towards overcoming policy resistance, Technological Forecasting and Social Change 111, 135-145.

[36] Geels, F., 2018. Disruption and low-carbon system transformation: Progress and new challenges in socio-technical transitions research and the Multi-Level Perspective. Energy Research \& Social Science 37, 224-231.

[37] Svensson, O., Nikoleris, A., 2018. Structure reconsidered: towards new foundations of explanatory transitions theory, Research Policy 47 (2), 462-473.

[38] Valente, T.W., 2005. Network models and methods for studying the diffusion of innovations. In: Carrington, P., Scott, J., Wasserman, S. (Eds.) Models and methods in social network analysis. Cambridge University Press: Cambridge, 98-119.

[39] Fadly, F., Fontes, F., June 2019. Geographical proximity and renewable energy diffusion: An empirical approach, Energy Policy 129, 422-435.

[40] IEA (International Energy Agency), 2011. World Energy Outlook 274.

[41] International Renewable Energy Agency (IRENA), March 2017. Renewable energy in district heating and cooling: A sector roadmap for REmap, Abu Dhabi. Available at http://www.irena.org/DocumentDownloads/Publications/IRENA_REmap_DHC_Report _2017.pdf [accessed 29.9 2017] 
[42] Lychuk T., Halverson, M., Evans, M., Roshchanka, V., December 2012. Analysis of the Russian market for building energy efficiency. Pacific Northwest National Laboratory operated by Battelle for the United States Department of Energy. Available at http://www.pnnl.gov/main/publications/external/technical_reports/PNNL-22110.pdf; [accessed 29.92017 ]

[43] The World Bank, 2014. Energy Efficiency in Russia: Untapped Reserves.

[44] Arkhangelsk government, November 2014. Концепция развития локального теплоснабжения на территории Архангельской области до 2030 года (The concept for developing local heating in the Arkhangelsk region until 2030), 382-PP. Available at:

http://www.aoresc.ru/index.php?option=com_content\&view=article\&id=645\&Itemid=8 1 (accessed 26.62019 ).

[45] Boute, A., 2012. Modernizing the Russian district heating sector: Financing energy efficiency and renewable energy investments under the new federal heat law. Pace Environmental Law Review 29 (3), 746-810.

[46] Government of the Russian Federation, $2^{\text {nd }}$ February 2017. Энергетическая стратегия России на период до 2035 года (Russian energy strategy until 2035).

[47] Government of the Russian Federation, $17^{\text {th }}$ November 2008. Об утверждении Концепции долгосрочного социально-экономического развития Российской Федерации на период до 2020 года (с изменениями на 28 сентября 2018 года) (On approval of the Concept of the long-term socio-economic development of the Russian Federation for the period up to 2020 (as amended on September 28, 2018), available at: http://docs.cntd.ru/document/902130343 (accessed 3.6 2019).

[48] Government of the Russian Federation, 30 ${ }^{\text {th }}$ March 2009. Основы государственной политики Российской федерации в Арктике на период до 2020 года и дальнейшую перпективу (State policy of the Russian Federation in the Arctic until 2020 and further perspective), available at:

http://static.government.ru/media/files/A4qP6brLNJ175I40U0K46x4SsKRHGfUO.pdf? fbclid=IwAR3V-bj8Xngrj9wRm8suXMT9O20D9ZwRrbjIHIVvK5bAP2NjZY8PC44w2U (accessed 5.7 2019).

[49] Russian Energy Agency, 2019. Алексей Беднов принял участие в заседании Экспертного совета фракции «СР» на тему «Парижское соглашение: нужна ли ратификация России?» ("Alexey Bednov took part in the meeting of the Expert Council of the CP fraction on the subject "Paris Agreement: Does Russia need ratification?") Available at: http://rosenergo.gov.ru/cur_news/2019-3-26/440/ (accessed $22.52019)$

[50] Putin, V., 13 ${ }^{\text {th }}$ May 2019 N 216 "Об утверждении Доктрины энергетической безопасности Российской Федерации" (Approving the energy security doctrine of the Russian Federation). 
[51] Smeets, N., 2018. The Green Menace: Unraveling Russia's elite discourse on enabling and constraining factors of renewable energy policies, Energy Research \& Social Science 40, 244-256.

[52] Voronov, D., 19th November 2015. Новая энергия в регионе будет "зеленой”, Arkhangelsk.

[53] Li, F., Strachan, N., 2017. Modelling energy transitions for climate targets under landscape and actor inertia, Environmental Innovation and Societal Transitions 24, 106129.

[54] Giddens, A., 1984. The Constitution of Society: Outline of the theory of structuration. Oxford: Polity Press.

[55] Pierson, P., 2000. Increasing returns, path dependence, and the study of politics. American Political Science Review 94 (2), 251-67.

[56] Aalto, P., Dusseault, D., Kivinen, M., Kennedy, MD., 2012. How are Russia's energy policies formulated? Linking the actors and structures of energy policy. In: Aalto, P, editor. Russia's Energy Policies: National, Interregional and Global Levels. Edward Elgar: Cheltenham, UK, p. 20-44.

[57] Aalto, P., Dusseault, D., Kivinen, M., Kennedy, MD., 2014. Russia's energy relations in Europe and the Far East: Towards a social structurationist approach to energy policy formation. Journal of International Relations and Development 17 (1), 129.

[58] Aalto, P., Bilgin, M., Talus, K., 2017. The political economy structures of energy transitions: From shale gas to renewable energy. Available at: https://www.eeg.tuwien.ac.at/conference/iaee2017/files/abstract/639_Aalto_abstract_20 17-06-30_09-19.pdf (accessed 6.9 2018)

[59] Salonen, H., 2018. Public justification analysis of Russian renewable energy strategies. Polar Geography 41(2), 75-86.

[60] Skryzhevska, Y., Tynkkynen, VP., Leppänen, S., 2015. Russia's climate policies and local reality. Polar Geography 2015; 38(2), 146-70.

[61] Poikonen, P. (ed.), 2014. Promotion of regional bioenergy initiatives in Poland, Romania and Slovakia. Final report. PromoBio Project IEE/10/470/SI2.593725.

[62] Khokhlov, A., Melnikov, Y., Veselov, F., Kholkin, D., Datsko, K., January 2018. Distributed energy resources in Russia: Development Potential. Published by the Moscow School of Management Skolkovo, available at: https://energy.skolkovo.ru/downloads/documents/SEneC/Research/SKOLKOVO_EneC _DER_2018.10.09_Eng.pdf (accessed 16.5 2019). 
(C) 2021. This manuscript version is made available under the CC-BY-NC-ND 4.0

license https://creativecommons.org/licenses/by-nc-nd/4.0/

https://doi.org/10.1016/j.eist.2019.10.006

[63] Smeets, N., 2017. Similar goals, divergent motives. The enabling and constraining factors of Russia's capacity-based renewable energy support scheme. Energy Policy $101,138-49$.

[64] Nekhebaeva G. От угля - до дров, Arkhangelsk 26 March 2015.

[65] Tynkkynen, VP., 2016. Energy as power - Gazprom, gas infrastructure, and geogovernmentality in Putin's Russia. Slavic Review 75(2), 374-95.

[66] Araujo, K., 2014. The emerging field of energy transitions: Progress, challenges, and opportunities. Energy Research \& Social Science 1, 112-21.

[67] Poelzer, G., Hoogensen Gjørv, G., Holdmann, G., Johnson, N., Mar Magnusson, B., Sokka, L., Tsyiachniouk, M., Yu, S. Developing renewable energy in Arctic and Sub-Arctic regions and communities: Working recommendations of the Fulbright Arctic Initiative Energy Group. University of Saskatchewan, International Centre for Northern Governance and Development.

\section{Appendix}

Table 1. Experts interviewed.

Table 2. Constraining and enabling factors in all dimensions. 